\title{
Potensi Bakteri Endofit sebagai Agens Hayati untuk Mengendalikan Penyakit Blas pada Tanaman Padi
}

\section{(Potency of Endophytic Bacteria as Biological Agent to Control Blast Disease on Rice)}

\author{
Husda Marwan*, Sosiawan Nusifera, Sri Mulyati \\ (Diterima Agustus 2020/Disetujui April 2021)
}

\begin{abstract}
ABSTRAK
Bakteri endofit merupakan salah satu kelompok mikrob yang berpotensi untuk dikembangkan sebagai agensia pengendalian hayati penyakit pada tanaman padi. Bakteri endofit yang diisolasi dari tanaman padi varietas lokal di Jambi telah diteliti mampu mengendalikan penyakit hawar daun bakteri pada tanaman padi. Selanjutnya diteliti potensi bakteri endofit tersebut dalam mengendalikan penyakit blas yang sebabkan oleh Pyricularia oryzae dan pengaruhnya pada produksi padi. Isolat bakteri endofit diuji daya hambatnya terhadap $P$. oryzae menggunakan metode biakan ganda. Isolat yang mampu menghambat pertumbuhan mikrob tersebut secara in vitro, selanjutnya diujikan pada tanaman padi varietas Cisadane. Akar bibit padi direndam dalam suspensi bakteri endofit selama 6 jam kemudian ditanam pada media tanah dan pupuk kandang steril. Patogen diinokulasikan dengan menyemprotkan suspensi konidia mikrob pada permukaan daun padi pada 14 hari setelah tanam. Hasil penelitian menunjukkan bahwa 10 isolat bakteri endofit mampu menghambat pertumbuhan $P$. oryzae sebesar $26,56-79,69 \%$. Perlakuan bakteri endofit pada bibit padi sebelum tanam mampu menghambat keparahan penyakit blas daun $23,90-65,42 \%$ dan blas malai $58,47-96,46 \%$, serta meningkatkan persentase gabah terisi.
\end{abstract}

Kata kunci: pengendalian hayati, padi, Pyricularia oryzae

\section{ABSTRACT}

Endophytic bacteria is one of the microbial groups that are potential to be developed as a biological control agent for disease in rice plants. The bacteria isolated from local varieties of rice plants in Jambi have been studied to be able to control bacterial leaf blight in rice plants. Further study was to determine the potential of these endophytic bacteria to control the blast disease caused by Pyricularia oryzae and its effect on rice production. The bacteria isolates were tested for inhibitory against $P$. oryzae using the dual culture method. The isolates that were able to inhibit the $\boldsymbol{P}$. oryzae growth in vitro were then tested on Cisadane rice plants. The roots of rice seedlings were immersed in a bacteria suspension for 6 hours, then planted on soil media and sterile manure. The pathogen was inoculated by spraying $P$. oryzae conidia suspension on the surface of the rice leaves 14 days after planting. The results showed that 10 isolates of endophytic bacteria inhibited the growth of $P$. oryzae at $26.56-79.69 \%$. The endophytic bacteria applied on the rice seedlings before planting has been able to inhibit leaf blast disease severity at $23.90-65.42 \%$ and $58.47-96.46 \%$ for panicle blast, as well as increasing the percentage of filled grain.

Keywords: biological control, Pyricularia oryzae, rice

\section{PENDAHULUAN}

Penyakit blas yang disebabkan oleh Pyricularia oryzae merupakan salah satu penyakit penting pada tanaman padi karena dapat menimbulkan kehilangan hasil $11-50 \%$ (Koutroubas et al. 2009). Penyakit blas menyerang tanaman mulai dari persemaian hingga fase generatif dengan bagian tanaman yang umum diserang adalah daun, ruas batang, tangkai malai, cabang malai, dan bulir padi. Infeksi patogen pada leher malai menyebabkan malai menjadi busuk dan bulir padi menjadi hampa (Hajano et al. 2011).

Fakultas Pertanian Universitas Jambi, Jl. Jambi-Muara Bulian KM 15 Muaro Jambi 36361

* Penulis Korespondensi:

Email: husda_marwan@unja.ac.id
Penyakit blas saat ini dikendalikan dengan menanam varietas tahan dan menggunakan pestisida. Pengembangan varietas padi tahan blas menghadapi kendala karena banyaknya ras patogen di lapangan, sedangkan penggunaan pestisida menyebabkan residu pada lingkungan dan gangguan pada ekosistem sawah. Untuk mengatasi hal tersebut, perlu dikembangkan metode pengendalian penyakit blas pada tanaman padi yang ramah lingkungan dan mudah diaplikasikan di lapangan. Pengendalian hayati untuk penyakit blas dengan memanfaatkan bakteri endofit dapat dikembangkan karena bakteri endofit hidup pada relung yang sama dengan patogen dan dapat beradaptasi dengan perubahan patogen di lapangan, sehingga memberikan efek pengendalian yang berkelanjutan. Bakteri endofit berperan penting bagi pertumbuhan dan biasanya hidup di dalam tanaman 
yang sehat tetapi tidak menyebabkan reaksi sebagai patogen (Ding \& Melche 2016).

Bakteri endofit saat ini banyak dimanfaatkan sebagai agens hayati karena menghasilkan senyawa antimikrob, zat pengatur tumbuh, memfiksasi nitrogen, dan memobilisasi fosfat yang berperan dalam memacu dan ketahanan tanaman (Ikeda et al. 2010; Etminani \& Harighi 2018). Munif et al. (2012) melaporkan beberapa isolat bakteri endofit asal padi gogo menunjukkan reaksi antibiosis terhadap $P$. oryzae secara in vitro. Hasil penelitian Chung et al. (2015) menunjukkan bahwa bakteri endofit yang diisolasi dari akar padi sawah mampu menghambat pertumbuhan miselia beberapa patogen pada tanaman padi seperti Fusarium oxysporum, P. oryzae, dan Rhizoctonia solani secara in vitro.

Bakteri endofit yang diisolasi dari tanaman padi verietas lokal Jambi telah diuji mampu meningkatkan mutu benih padi yang terinfeksi Xanthomonas oryzae pv. oryzae; perlakuan tersebut mampu meningkatkan jumlah benih yang berkecambah dan menekan persentase benih yang terinfeksi (Marwan et al. 2015). Perlakuan bakteri endofit dan rizobakteri pada bibit padi mampu menekan keparahan penyakit hawar daun bakteri sebesar 76,17-86,61\%, dan berpengaruh pada tinggi tanaman, jumlah anakan, jumlah malai, dan bobot gabah berisi, serta mampu mengurangi persentase gabah hampa (Marwan et al. 2017). Penelitian ini bertujuan mengevaluasi kemampuan bakteri endofit dalam menghambat pertumbuhan $P$. oryzae, dalam mengendalikan penyakit blas pada tanaman padi dan pengaruhnya pada produksi tanaman padi.

\section{METODE PENELITIAN}

\section{Isolat Bakteri Endofit dan P. oryzae}

Sebanyak 32 isolat bakteri endofit yang diuji pada penelitian ini merupakan koleksi Tim Peneliti, diisolasi dari beberapa tanaman padi varietas lokal di Jambi. Isolat $P$. oryzae berasal dari koleksi Laboratorium Penyakit Tanaman, Fakultas Pertanian, Universitas Jambi.

\section{Uji Kemampuan Bakteri Endofit dalam Menghambat Pertumbuhan $P$. oryzae}

Pengujian ini bertujuan menentukan bakteri endofit yang mampu menghambat pertumbuhan $P$. oryzae pada medium potato dextrose agar (PDA). Sebelum diuji, isolat bakteri endofit dibiakkan pada media tryptic soy agar (TSA) selama 48 jam dan $P$. oryzae dibiakkan pada media PDA selama 7 hari. Pengujian menggunakan metode kultur ganda (Jaiganesh et al. 2007). Potongan miselium $P$. oryzae pada media PDA (diameter $5 \mathrm{~mm}$ ) diletakkan pada jarak $25 \mathrm{~mm}$ dari tepi cawan petri; pada bagian yang berlawanan digoreskan isolat bakteri endofit yang diuji dengan jarak $25 \mathrm{~mm}$ dari tepi cawan petri. Setiap isolat bakteri endofit diuji 2 kali dengan waktu pengujian yang berbeda.
Pertumbuhan $P$. oryzae yang menuju ke arah bakteri dan berlawanan arah bakteri diamati pada hari ke-7, persentase penghambatan dihitung dengan rumus:

$$
P=\frac{\mathrm{R} 1-\mathrm{R} 2}{\mathrm{R} 1} \times 100 \%
$$

Keterangan:

$P \quad=$ Persentase penghambatan pertumbuhan (\%)

$R 1=$ Jarak jari-jari miselium $P$. oryzae ke arah tepi cawan petri $(\mathrm{cm})$

$R 2=$ Jarak jari-jari miselium $P$. oryzae ke bakteri endofit $(\mathrm{cm})$

\section{Uji Bakteri Endofit untuk Mengendalikan Penyakit Blas pada Tanaman Padi}

Pengujian ini dimaksudkan untuk mendapatkan bakteri endofit yang mampu menekan perkembangan penyakit blas pada tanaman padi. Pengujian disusun dalam rancangan acak lengkap dengan 12 perlakuan dan 5 ulangan. Perlakuan terdiri atas 10 bakteri endofit yang menunjukkan penghambatan $P$. oryzae secara in vitro (isolat BE-KT1, BE-KT2, BE-KT4, BE-KR3, BES1, BE-S7, BE-M1, BE-M2, BE-M3, BE-M4) dan 2 perlakuan sebagai kontrol (kontrol penyakit dan fungisida berbahan aktif Mankozeb).

Isolat untuk aplikasi pada bibit padi diperbanyak pada media cair Pepton $5 \%$. Sebanyak $1 \mathrm{~mL}$ suspensi koloni tunggal bakteri ditambahkan pada $100 \mathrm{~mL}$ medium Pepton 5\% (5 g pepton dalam $1.000 \mathrm{~mL}$ akuades), kemudian dikocok selama 48 jam dengan kecepatan 120 rpm pada suhu ruang. Suspensi bakteri diatur konsentrasinya menjadi $10^{8}-10^{9}$ sel $\mathrm{mL}^{-1}$.

Bibit padi varietas Cisadane umur 21 hari setelah semai direndam selama 6 jam dalam suspensi bakteri (Marwan et al. 2011). Bibit kemudian ditanam pada ember yang berisi media tanam campuran tanah dan pupuk kandang dengan nisbah 1:1 (v/v) yang telah disterilkan.

Isolat $P$. oryzae diperbanyak pada media oatmeal agar. Potongan miselium diinokulasikan pada media oatmeal agar (30 g oat/L, $20 \mathrm{~g}$ agar-agar/L, $5 \mathrm{~g}$ sukrosa/L), dan diinkubasi selama 7 hari pada suhu ruang, kultur selanjutnya diinkubasikan dalam inkubator bercahaya $20 \mathrm{~W}$ NUV, $30 \mathrm{~cm}$ di atas kultur dengan panjang gelombang 350-500 nm (Dahlberg \& Etten 1982) menggunakan metode 12 jam terang dan 12 jam gelap selama 7 hari (Leach 1962) untuk menginduksi pembentukan konidia.

$P$. oryzae diinokulasi pada tanaman padi umur 14 hari setelah tanam dengan menyemprotkan suspensi konidia dengan kerapatan $10^{5}$ konidia $\mathrm{mL}^{-1}$ (Nasution \& Usyati 2015). Tanaman ditempatkan di rumah kasa yang dijaga kelembapannya dengan pemasangan springkel embun dan paranet. Tanaman dipelihara dari gulma secara teknis dan diberi pupuk anorganik sesuai anjuran (Apriyantono 2007).

Peubah yang diamati adalah keparahan dan kejadian penyakit blas, bobot gabah, dan persentase 
gabah terisi. Keparahan penyakit blas daun menggunakan skala infeksi penyakit blas pada daun padi (Tabel 1). Keparahan penyakit blas daun dihitung dengan rumus:

$$
\mathrm{KP}=\frac{\sum(\mathrm{ni} \times \mathrm{vi})}{\mathrm{N} \times \mathrm{Z}}
$$

Keterangan:

$\mathrm{KP} \quad=$ Keparahan penyakit

$n_{\mathrm{i}} \quad=$ Jumlah daun terinfeksi skala ke $\mathrm{i}$

$v_{\mathrm{i}} \quad=$ Skala daun terinfeksi ke $\mathrm{i}$

$N \quad=$ Jumlah seluruh daun yang diamati

$Z \quad=$ Skala penyakit tertinggi.

Kejadian penyakit blas malai dihitung menggunakan rumus:

$$
T=\frac{n t}{N} \times 100 \%
$$

Keterangan:

$T=$ Kejadian penyakit blas malai

nt = Jumlah malai terserang

$N \quad$ = Jumlah malai yang diamati

Bobot gabah ditentukan dengan cara merontokkan semua gabah yang telah dipanen per rumpun. Selanjutnya gabah ditimbang dalam satuan gram kemudian dipisahkan antara gabah terisi dan gabah hampa. Persentase gabah terisi dihitung dengan membandingkan bobot gabah terisi dengan bobot gabah setiap rumpun.

Data keparahan dan kejadian penyakit blas serta bobot gabah dan persentase gabah terisi dihitung untuk menilai pengaruh perlakuan bakteri endofit pada perkembangan penyakit blas dan produksi tanaman melalui analisis ragam dan dilanjutkan dengan uji Berganda Duncan pada taraf 5\%.

\section{HASIL DAN PEMBAHASAN}

\section{Kemampuan Bakteri Endofit Menghambat Pertumbuhan $\boldsymbol{P}$. oryzae}

Hasil uji in vitro pada 32 isolat bakteri endofit dalam menghambat pertumbuhan $P$. oryzae menunjukkan bahwa 10 isolat mampu menghambat pertumbuhan miselium $P$. oryzae dengan persentase penghambatan $26,56-79,69 \%$ (Tabel 2), sedangkan 22 isolat lainnnya tidak menunjukkan daya hambat. Sebanyak 7 dari 10 isolat yang mampu menghambat pertumbuhan $P$. oryzae mempunyai persentase penghambat lebih dari $50 \%$.

Hasil uji kultur ganda secara in vitro pada Tabel 1 menunjukkan bahwa beberapa isolat bakteri endofit dari tanaman padi mampu menghambat pertumbuhan koloni $P$. oryzae. Hal ini ditandai dengan keberadaan zona bening dan terhambatnya pertumbuhan miselium cendawan. Pertumbuhan yang cepat dari bakteri endofit dapat menghambat pertumbuhan koloni karena terjadi kompetisi ruang tumbuh dan sekresi senyawa antibiosis pada media sehingga memunculkan zona bening di sekeliling koloni $P$. oryzae (Gambar 1 ).

Terhambatnya pertumbuhan miselum jamur $P$. oryzae diduga disebabkan oleh senyawa antifungi yang dihasilkan oleh bakteri endofit. Menurut Zhou et al. (2014) bakteri endofit dapat menghasilkan beberapa komponen di lingkungannya, seperti produksi senyawa volatil organik, sekresi antibiotik, dan enzim lisis. Senyawa antifungi dapat mengganggu dinding sel jamur mengakibatkan hifa menjadi melengkung, kecil, bengkak, dan lisis/pecah (Minaxi

Tabel 1 Skala infeksi penyakit blas pada daun padi (IRRI1996)

\begin{tabular}{cl}
\hline Skala & \multicolumn{1}{c}{ Tingkat gejala serangan penyakit pada daun } \\
\hline 0 & Tidak ada gejala serangan \\
1 & Terdapat bintik cokelat kecil \\
3 & Bintik cokelat bulat sampai agak lonjong (diameter $1-2 \mathrm{~mm})$ \\
5 & Luka berbentuk elips, lebar $1-2 \mathrm{~mm}$, panjanglebih dari $3 \mathrm{~mm}(4-10 \%$ luas daun) \\
7 & Bercak khas blas dengan pinggiran daun berwarna kuning, cokelat atau ungu (26-50\% luas daun) \\
9 & Bercak khas blas, warna abu-abu keputihan( $\geq 75 \%$ luas daun atau daun mati) \\
\hline
\end{tabular}

Tabel 2 Kemampuan bakteri endofit menghambat pertumbuhan $P$. oryzae

\begin{tabular}{lcc}
\hline Perlakuan isolat bakteri endofit & $\begin{array}{c}\text { Diameter koloni } \\
P . \text { oryzae }(\mathrm{cm})\end{array}$ & $\begin{array}{c}\text { Kemampuan penghambatan } \\
(\%)\end{array}$ \\
\hline Kontrol & $6,4^{*}$ & - \\
BE-KT1 & 2,5 & 60,94 \\
BE-KT2 & 1,7 & 73,44 \\
BE-KT4 & 2,0 & 68,75 \\
BE-KR3 & 1,3 & 79,69 \\
BE-S1 & 2,3 & 64,06 \\
BE-S7 & 1,6 & 75,00 \\
BE-M1 & 2,2 & 65,63 \\
BE-M2 & 4,4 & 31,25 \\
BE-M3 & 4,7 & 26,56 \\
BE-M4 & 4,3 & 32,81 \\
\hline
\end{tabular}

Keterangan: * Diameter koloni merupakan rata-rata dari 2 kali pengujian 
2010). Senyawa volatil yang dihasilkan oleh bakteri endofit menghambat pertumbuhan koloni $P$. oryzae serta menyebabkan kerusakan morfologi (malformasi) pada hifanya (Widiantini \& Hartati 2020).

\section{Kemampuan Bakteri Endofit dalam Mengendalikan Penyakit Blas pada Tanaman Padi}

Serangan $P$. oryzae pada tanaman padi menyebab gejala blas daun dan blas malai. Pada tanaman stadium vegetatif biasanya patogen menginfeksi bagian daun, disebut blas daun, sedangkan pada stadium generatif selain menginfeksi daun juga menginfeksi leher malai disebut blas malai (Sudir et al. 2014). Hasil pengamatan keparahan penyakit blas daun dan kejadian penyakit blas malai menunjukkan bahwa tanaman yang diberi perlakuan bakteri endofit memiliki keparahan penyakit blas daun dan kejadian blas malai lebih rendah dibandingkan dengan tanaman control penyakit. Perlakuan bakteri endofit pada bibit padi sebelum tanaman mampu menekan keparahan penyakit blas daun $23,90-65,5 \%$ dan kejadian penyakit blas malai $58,47-96,46 \%$ (Tabel 3). Isolat BE-KR3 menunjukkan penekanan keparahan penyakit blas daun paling tinggi, yaitu $65,5 \%$, sedangkan penekanan kejadian penyakit blas malai paling tinggi ditunjukkan oleh isolat BE-KT2, yaitu 96,46\%.

Penyakit blas daun dapat memengaruhi kejadian penyakit blas malai, bergantung pada tingkat keparahan penyakit blas daun. Keparahan penyakit blas daun yang tinggi menyebabkan jumlah inokulum patogen pada tanaman menjadi lebih banyak sehingga berpotensi menginfeksi semua daun yang muncul dari anakan tanaman padi. Apabila menginfeksi daun bendera, maka inokulum berpotensi menyebabkan infeksi pada tangkai malai yang berada dekat dengan daun bendera. Menurut Hajano et al. (2011) infeksi patogen pada daun bendera akan mengakibatkan blas malai sehingga malai menjadi busuk dan bulir padi menjadi hampa.

Kemampuan bakteri endofit menekan perkembangan patogen erat kaitannya dengan kemampuannya menghasilkan senyawa antimikrob, penguasaan relung atas patogen, menginduksi ketahanan sistemik dan meningkatkan toleransi tanaman terhadap tekanan lingkungan (Agrios 2005). Chung et al. (2015) melaporkan bahwa bakteri endofit menghasilkan senyawa peptida dan lipopeptida, seperti fengisin, iturin, dan surfaktin, yang berperan dalam menginduksi ketahanan sistemik.
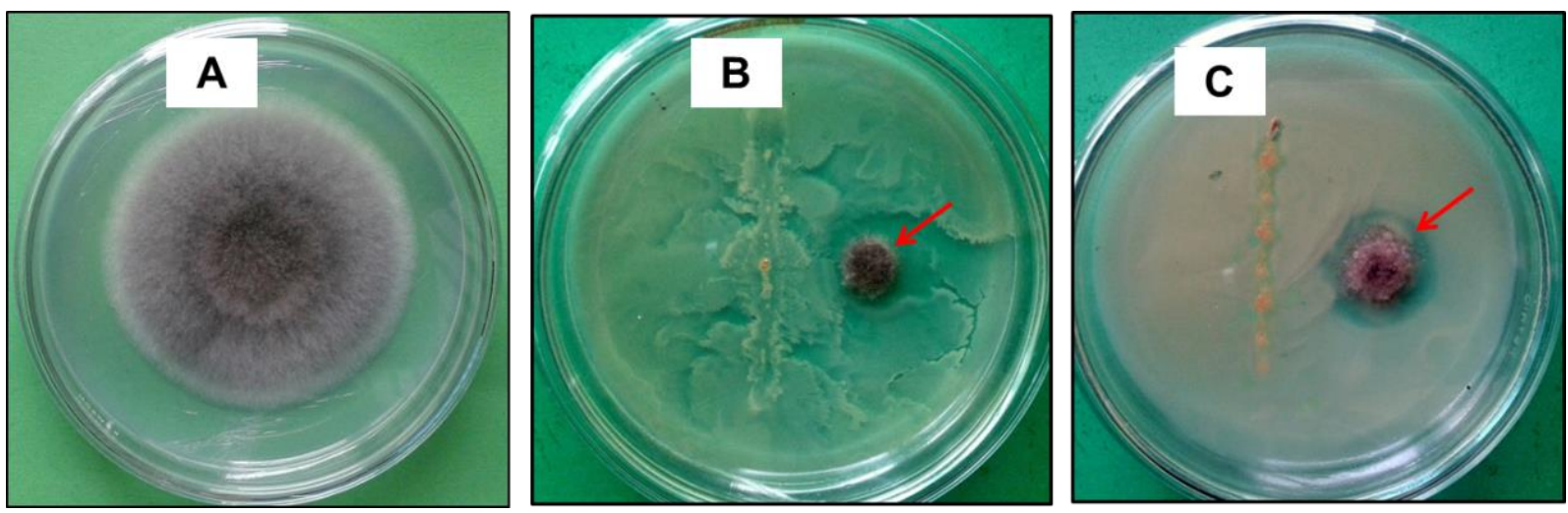

Gambar 1 Uji kultur ganda isolat bakteri endofit terhadap $P$. oryzae. A) Isolat $P$. oryzae; B) Isolat BE-S1 dengan P. oryzae; dan $\mathrm{C}$ ) Isolat BE-KR3 dengan $P$. oryzae. Tanda panah warna merah menunjukkan koloni $P$. oryzae.

Tabel 3 Pengaruh perlakuan bakteri endofit pada keparahan penyakit blas daun dan kejadian blas malai pada tanaman padi

\begin{tabular}{|c|c|c|c|c|}
\hline Perlakuan isolat bakteri endofit & $\begin{array}{c}\text { Keparahan blas } \\
\text { daun (\%) }\end{array}$ & $\begin{array}{c}\text { Penekanan } \\
\text { keparahan blas } \\
\text { daun (\%) }\end{array}$ & $\begin{array}{l}\text { Kejadian blas } \\
\text { malai }(\%)\end{array}$ & $\begin{array}{c}\text { Penekanan kejadian } \\
\text { blas malai (\%) }\end{array}$ \\
\hline Kontrol penyakit & $70,67^{a^{*}}$ & - & $26,533^{a b^{*}}$ & - \\
\hline Fungisida & $33,78 b c$ & 52,20 & $9,58^{c}$ & 86,44 \\
\hline BE-KT1 & 34,22 bc & 51,58 & $11,87 b c$ & 83,20 \\
\hline BE-KT2 & $38,67^{b}$ & 45,28 & $2,50^{c}$ & 96,46 \\
\hline BE-KT4 & $35,11^{b}$ & 50,32 & $3,34^{c}$ & 95,27 \\
\hline BE-S1 & $39,56^{b}$ & 44,02 & $14,62 a b c$ & 79,31 \\
\hline BE-S7 & $36,00^{b}$ & 49,06 & $7,00^{\mathrm{c}}$ & 90,09 \\
\hline BE-KR3 & $24,44^{d}$ & 65,42 & $6,50^{c}$ & 90,80 \\
\hline BE-M1 & $44,00^{b}$ & 37,74 & $10,28^{c}$ & 85,45 \\
\hline BE-M2 & $37,78^{b}$ & 46,54 & $8,06^{c}$ & 88,59 \\
\hline BE-M3 & $53,78^{a}$ & 23,90 & $16,37 \mathrm{abc}$ & 76,84 \\
\hline BE-M4 & 52,89 a & 25,16 & 29,35 a & 58,47 \\
\hline
\end{tabular}

Keterangan: * Angka pada kolom yang sama yang diikuti huruf yang sama tidak berbeda nyata berdasarkan uji berganda Duncan pada taraf $5 \%$. 


\section{Pengaruh Bakteri Endofit pada Produksi Tanaman Padi}

Perlakuan bakteri endofit pada bibit padi tidak berpengaruh pada bobot gabah, tetapi berpengaruh pada persentase gabah berisi (Tabel 4). Setiap isolat bakteri endofit tidak menunjukkan pengaruh yang berbeda pada persentase gabah berisi dengan isolat lainnya. Hal ini menunjukkan bahwa semua perlakuan bakteri endofit pada bibit padi sebelum tanam mampu menghambat perkembangan gejala blas pada malai padi yang dapat memengaruhi proses pengisian gabah. Berdasarkan temuan Khan et al. (2014), infeksi blas malai menyebabkan meningkatnya persentase bulir padi yang steril dan menurunkan bobot bulir.

Secara konseptual, bakteri endofit dapat memengaruhi pertumbuhan tanaman baik secara langsung maupun tidak langsung. Secara tidak langsung, bakteri membatasi atau mencegah kerusakan tanaman yang mungkin disebabkan oleh berbagai patogen termasuk bakteri dengan cara produksi antibiotik, enzim pengurai dinding sel, menurunkan tingkat etilena tanaman, menginduksi resistensi sistemik, menurun jumlah zat besi yang tersedia untuk patogen, dan sintesis senyawa volatil yang menghambat patogen (Glick 2012).

Pengaruh bakteri endofit pada produksi tanaman padi yang terinfeksi oleh $P$. oryzae terjadi karena bakteri endofit mampu menyediakan faktor yang dibutuhkan oleh tanaman saat terjadi infeksi sehingga tanaman tumbuh dengan baik. Menurut Bustami et al. (2012), produksi tanaman padi akan mencapai optimum jika faktor pendukung pertumbuhan tanaman berada dalam keadaan optimal dan nutrisi yang dibutuhkan tersedia bagi tanaman. Backman \& Sikora (2008) melaporkan bahwa keberadaan bakteri-bakteri endofit di dalam jaringan tanaman dapat berperan dalam memperbaiki pertumbuhan tanaman (plant growth promotion), menghasilkan zat pemacu tumbuh, memfiksasi nitrogen, memobilisasi fosfat, dan berperan dalam kesehatan tanaman (plant health promotion). Mbai et al. (2013) juga melaporkan bahwa bakteri endofit yang berasal dari akar tanaman padi (Pseudomonas fluorescens dan Bacillus thuringiensis) mampu menghasilkan hormon pertumbuhan tanaman seperti asam indol asetat, dan mampu mengikat nitrogen yang dapat memperbaiki pertumbuhan tanaman padi.

Hasil penelitian ini menunjukkan bahwa bakteri endofit berpotensi untuk dikembangkan sebagai agens pengendalian hayati terhadap penyakit blas pada tanaman padi yang disebabkan oleh $P$. oryzae. Penggunaan bakteri endofit pada bibit padi mendukung pengelolan tanaman yang ramah lingkungan dan berkelanjutan.

\section{KESIMPULAN}

Isolat bakteri endofit dari tanaman padi berhasil menekan pertumbuhan koloni $P$. oryzae 32,81 $79,69 \%$. Perlakuan bakteri endofit pada bibit padi sebelum tanam mampu menekan keparahan penyakit blas daun $23,90-65,42 \%$ dan kejadian penyakit blas malai $58,47-96,46 \%$, serta meningkatkan persentase gabah berisi pada tanaman yang terinfeksi $P$. oryzae.

\section{UCAPAN TERIMA KASIH}

Ucapan terima kasih penulis sampaikan kepada Direktorat Riset dan Pengabdian kepada Masyarakat, Kemeristek Dikti yang telah membiayai penelitian ini melalui skema penelitian Strategis Nasional tahun 2017.

\section{DAFTAR PUSTAKA}

Agrios GN. 2005. Plant Pathology. 5rd Edition. San Diego (US): Academic Press.

Apriyantono A. 2007. Acuan Penetapan Rekomendasi Pupuk N, P, dan K Pada Lahan Sawah Spesifik Lokasi (Per Kecamatan). Dalam Lampiran Permentan Nomor 40/Permentan/OT.140/04/2007. Jakarta (ID).

Backman PA, Sikora RA. 2008. Endophytes: an emerging tool for biological control. Journal

Tabel 4 Pengaruh bakteri endofit pada bobot gabah dan persentase gabah berisi

\begin{tabular}{lcc}
\hline \multicolumn{1}{c}{ Perlakuan isolat bakteri endofit } & Bobot gabah $(\mathrm{g})$ & Persentase gabah berisi $(\%)$ \\
\hline Kontrol penyakit & 48,10 & $77,32^{\mathrm{b}^{*}}$ \\
Fungisida & 63,86 & $88,31^{\mathrm{a}}$ \\
BE-KT1 & 49,92 & $89,00^{\mathrm{a}}$ \\
BE-KT2 & 63,94 & $88,033^{\mathrm{a}}$ \\
BE-KT4 & 55,48 & $89,34^{\mathrm{a}}$ \\
BE-S1 & 50,94 & $91,71^{\mathrm{a}}$ \\
BE-S7 & 54,86 & $89,933^{\mathrm{a}}$ \\
BE-KR3 & 53,92 & $90,01^{\mathrm{a}}$ \\
BE-M1 & 59,58 & $84,89^{\mathrm{a}}$ \\
BE-M2 & 66,74 & $88,57^{\mathrm{a}}$ \\
BE-M3 & 69,64 & $85,61^{\mathrm{a}}$ \\
BE-M4 & 56,88 & $90,07^{\mathrm{a}}$ \\
Keterangan: ${ }^{*}$ Angka pada kolom yang sama yang diikuti huruf yang sama tidak berbeda nyata berdasarkan uji berganda
\end{tabular}


Biological Control. 46(1): 1-3. https:// doi.org/10.1016/j.biocontrol.2008.03.009

Bustami, Sufardi, Bakhtiar. 2012. Serapan hara dan efisiensi pemupukan phosfat serta pertumbuhan padi varietas local. Jurnal Manajemen Sumberdaya Lahan. 1(2): 159-170.

Chung EJ, Hossain MT, Khan A, Kim KH, Jeon CO, Chung YR. 2015. Bacillus oryzicola sp. nov., an endophytic bacterium isolated from the roots of rice with antimicrobial, plant growth promoting, and systemic resistance inducing activities in rice. Journal of Plant Pathology. 31(2): 152-164. https://doi.org/10.5423/PPJ.OA.12.2014.0136

Ding T, Melcher U. 2016. Influences of plant species, season and location on leaf endophytic bacterial communities of non-cultivated plants. PLOS ONE. 11(3): e0150895. https://doi.org/10.1371/journal. pone. 0150895

Etminani F, Harighi B. 2018. Isolation and identification of endophytic bacteria with plant growth promoting activity and biocontrol potential from wild pistachio trees. Plant Pathology Journal. 34(3): 208-217. https://doi.org/10.5423/PPJ. OA.07.2017.0158

Fukuta Y, Koga I, Ung T, Sathya K, Kawasaki-Tanaka A, Koide Y, Kobayashi N, Obara M, Yagana H, Hayashi N. 2014. Pathogenicity of rice blast (Pyricularia oryzae Cavara) isolates from Cambodia. Japan Agricultural Research Quarterly. 48: 155-166. https://doi.org/10.6090/jarq.48.155

Glick BR. 2012. Plant growth-promoting bacteria: mechanisms and applications. Scientifica. 2012 : 115. https://doi.org/10.6064/ 2012/963401

Hajano J, Pathan MA, Rajput AQ, Lodhi AM. 2011. Rice blast-mycoflora, symptomatology and pathogenicity. International Journal for Agro Veterinary and Medical. 5(1): 53-63.

Ikeda S, Okubo T, Anda M, Nakashita H, Yasuda M, Sato S, Kaneko T, Tabata S, Eda S, Momiyama A, Terasawa K. 2010. Community and genome based views of plant associated bacteria: plant bacterial interactions in soybean and rice. Plant Cell Physiology. 51(9): 1398-1410.

[IRRI] International Rice Research Institute. 1996. Standard Evaluation System for Rice. $4^{\text {th }}$ ed. International Rice Testing Program IRRI. Los Banos, Philippines. 54p.

Jaiganesh V, Eswaran A, Balabaskar P, Kannan C. 2007. Antagonistic activity of Serratia marcescens against Pyricularia oryzae. Notulae Botanicae Horti Agrobotanici Cluj-Napoca. 35(2): 48-54.

Koutroubas SD, Katsantonis D, Ntanos DA, Lupotto E. 2009. Blast disease influence on agronomic and quality traits of rice varieties under Mediterranean conditions. Turki Journal Agriculture. 33: 487-494.
Marwan H, Mapegau, Nusifera S, Mulyati S. 2017. Pengaruh Perlakuan Bakteri Endofit dan Rizobakteri pada Bibit Padi Terhadap Perkembangan Penyakit Hawar Daun Bakteri (Xanthomonas oryzae pv. oryzae)dan Pertumbuhan Tanaman Padi di Rumah Kaca. Proseding Seminar Nasional Pengendalian Penyakit pada Tanaman Ramah Lingkungan II, Yogyakarta (ID): 27 Agustus 2016.

Marwan H, Mapegau. 2014. Bakteri endofit dan rizobakteri sebagai agens pengendalian hayati penyakit hawar daun bakteri (Xanthomonas oryzae pv. oryzae) dan pemacu pertumbuhan tanaman padi. Proseding Semirata BKS Indonesia Bagian Barat, Lampung (ID), 19-20 Agustus 2014.

Marwan H, Sinaga MS, Giyanto, Nawangsih AA. 2011. Isolasi dan seleksi bakteri endofit untuk pengendalian penyakit darah pada tanaman pisang. Jurnal Hama Dan Penyakit Tumbuhan Tropika. 11(2): 113-121.

Mbai FN, Magiri EN, Matiru VN, Ng'ang'a J, Nyambati VCS. 2013. Isolation and characterisation of bacterial root endophytes with potential to enhance plant growth from kenyan basmati rice. American International Journal of Contemporary Research. $3(4): 25-40$

Minaxi JS. 2010. Characterization of Pseudomonas aeruginosa RM-3 as a Potential Biocontrol Agent. Mycopathologia. 170: 181-193. https://doi.org/ 10.1007/s11046-010-9307-4

Munif A, Wiyono S, Suwarno. 2012. Isolasi bakteri endofit asal padi gogo dan potensinya sebagai agens biokontrol dan pemacu pertumbuhan. Jurnal Fitopatologi Indonesia. 8(3): 57-64.

Nasution A, Usyati N. 2015. Observasi ketahanan varietas padi lokal terhadap penyakit blas (Pyricularia grisea) di Rumah Kaca. Proseding Seminar Nasional Masyarakat Biodiversitas Indonesia, Depok (ID), 20 Desember 2014.

Strobel G, Daisy B. 2003. Bioprospecting for Microbial Endophytes and Their Natural Products. Microbiology and Molecular Biology Reviews Microbiol. 67: 491-502. https://doi.org/10.1128/ MMBR.67.4.491-502.2003

Sudir, Nasution A, Santoso, Nuryanto B. 2014. Penyakit Blas Pyricularia grisea pada Tanaman Padi dan Strategi Pengendaliannya. Iptek Tanaman Pangan. 9(2): 85-95.

Widiantini F, Hartatis F. 2020. Endophytic bacteria of healthy rice plants origin produce antifungal volatile compound inhibiting the in vitro growth of Pyricularia oryzae Cav., the causal agent of rice blast disease. Jurnal Cropsaver. 3(1): 31-36. 